\title{
The Fallacy of Religious Fundamentalism and Its Ontological Boomerang Effect; An African Worldview
}

\author{
Edeh, Peter Daniel \\ Department of Philosophy, University of Abuja, Abuja, Nigeria \\ Email: pedeeh@gmail.com
}

Received 20 October 2014; accepted 20 March 2015; published 23 March 2015

Copyright $@ 2015$ by authors and Scientific Research Publishing Inc.

This work is licensed under the Creative Commons Attribution International License (CC BY).

http://creativecommons.org/licenses/by/4.0/

c) (i) Open Access

\begin{abstract}
That Adam exists in the mind of man, creates a belief system that lacks or defies the principle directives of complementary reflection in the right direction which is rooted in the very idea of religious fundamentalism which envelopes the Existential Phenomenological Ontology of Human Predicament. This fact is reflected in the un-mutual and the resulting destabilization in some organized practices among the religious sector in the world. Consequently, there is an ontological boomerang effect. This paper takes a complementary reflection on the ontological boomerang effect of religious fundamentalism as it defies existence in African world view. Put simply, egbe bere ugo bere, onye sina ibeya ebena, ukwu kwayai..
\end{abstract}

\section{Keywords}

Fundamentalism, Ontological Boomerang, Complementarism (Egbebere Ugo Bere), African Worldview

\section{Introduction}

That Adam exists in the mind of man is a phenomena which existed within the context of world religions as created for our understanding which the world have so accepted and believed without questioning. The way and manner the world have accepted this fact bedevils its ontological existence which has been made factual upon naïve realism. African world view though may not share the same view as in the same context in which Adam exists in the mind of man, it is expressed in the context of African language as can be seen in Igede language; “Adam” meaning my father "Ada” meaning "father" from the verb "to be”, “Adida” meaning "fatherness". This in many other African languages has no bearing with the Biblical or Qur' anic Adam. However, there is discon- 
nect that ruminated fundamentalism; this same disconnect falls short of its ontological existence while acclaiming same descendance.

The idea of fundamentalism is a very peculiar one in the world. In this work, we have recognized three main strands of religion as practiced in our society. They include Islam, Christianity, and African Traditional Religions. This paper examines briefly the meaning of fundamentalism with its historical background among Christianity and Islam. The paper also examines the concept of boomerang effect with a comparative analysis among the religions while making passing reference to African traditional religions, as they influence only those who patronize the sorcerers, native doctors, juju priests, etc. Our traditional rulers are not left out as they are the custodians of our customs and traditions.

\section{Fundamentalism}

The concept of fundamentalism is an age-long term which, because of its usage, is better described than defined. The term is derived from the Latin "fundus", meaning "bottom", and "fundamentum", which entails the basic principles.

Webster's $(2004,512)$ gave an encyclopedic definition of fundamentalism as "the belief that all statements made in the Bible are literally true". Such belief was uplifted by some fundamentalist movements among Protestant Christians in the United States of America. This is essential to the Christian's faith as opposed to Modernism.

\section{Historical Overview}

The problem of religious fundamentalism is present in all the world's religions, but as said earlier, due to certain constraints and in order not to exceed the scope of this paper even though it is a broad-based topic, we will concentrate on two of the world's religions which are found dominant in our society: Christianity and Islam.

\section{Christianity}

Etymologically, fundamentalism among the Christians started in the United States of America way back in the $18^{\text {th }}$ century AD, among the Protestant Conservative Movement in American Protestantism, which came up as a result of the Millennium Movement then. Their point of emphasis was, as fundamental to Christianity:

The literal interpretation and absolute inherency of the scriptures, the imminent and the physical Second Coming of Jesus Christ, the Virgin Birth, Resurrection and Atonement (Britannica vol. 5, 51-52).

This paper gathered that, there was a scattered interest about The Millennium, but it was put together and a larger movement was formed through the Niagara Bible Conference initiated by one James Inglis, a New York City Baptist, shortly before his death in 1872. The conference continued under the leadership of a Presbyterian minister of St. Louis, James H. Brookes (1830-1897), and so on.

By the early $20^{\text {th }}$ century, fundamentalism became an opposition to Modernism in American religious and secular life, and by the latter part of the $20^{\text {th }}$ century, the movement was represented by numerous church bodies, educational institutions and special interest organizations

\section{Developmental Phases of Fundamentalism}

There are four developmental phases of fundamentalism. They include:

1) The fundamentalist view period;

2) The fundamentalist/modernist controversy period; and

3) Institutional development period;

4) The African Phase.

\subsection{The Fundamentalist View Period}

This was the beginning of the Millennium Movement. It started with the loss of confidence in America's destiny among some Protestant leaders, with the labor unrest, social discontent and the rising tide of Roman Catholic immigration. By 1902, the Millenarian influence on Conservative Protestantism came to its high point when they cooperated with other defenders of the inherency of the Bible in funding the writing of the series of twelve pamphlets entitled, "The Fundamental". Their writing was an attack on the current theories of biblical criticism. 
They tried to reassert authority by using some arguments developed in Briston Theological Seminary. Consequently, there was a militant and uncompromising younger generation which did not see the task of time as they also disagreed on the prophetic interpretation. These disagreements however led to the abandonment of the Niagara Conference, followed by a paper war between two leading Millenarian periodicals, Watch Word and Truth and our Hope (Britannica).

\subsection{The Fundamentalist/Modernist Controversy}

This period started after the World War I. The fundamentalists were alarmed by the growth of liberalism which they conceived to be social degeneracy. They reiterated the creedal basis of the movement and called for the exorcism of Modernism and all demons related to it. Notwithstanding that, more controversies continued to exist, which resulted in the breakage among the conservatives and the liberalists in both the Presbyterian and the Baptist church.

\subsection{Institutional Development Phase}

This period witnessed the development of the institutional phase of modern fundamentalism, owing to the backdrops of conflict in past years which caused the breakaway earlier mentioned. There came up a crop of fundamentalist associations among different churches, professors in the universities and students as well as seminaries. There were intervarsity Christian fellowships and campus crusades for Christ in hundreds of universities and colleges to give religious support similar to those provided by the protestant organization and Roman Catholics, paralleling the Ecumenical bodies of Protestantism and the American Council of Christian Churches (ACCC 1941). After the World War II, the public image of the fundamentalist was exemplified in the evangelist Billy Graham.

\subsection{The African Phase}

In the tropical Africa, Christianity is said to have begun towards the extinction of the $18^{\text {th }}$ century, with the founding of the Christian Missionaries Societies. They were basically the Catholics, Protestants (of the historical orthodox churches) and non denominational (fundamentalists). They all had their characteristics and spirituality. Unlike Islam, Christianity exists distinctly from the state, though in the Catholic Church for instance, submission to the Roman Catholic authority is of great importance. The Roman authority ensures that all leaders of the church in various countries were trained in Rome. To facilitate this effort, many large seminaries were built in Rome to accommodate them. Religious orders were made to hold their headquarters in Rome. What this implies is that there was no more room for theological trends.

Besides, the trend of fundamentalism continued in Africa as a result of the missionaries' failure to hearken to the yearning of the African people. Especially among the Protestants, this gave rise to churches like the Zionists in South Africa, and the Aladura in Nigeria. According to Todd (1962: 176), this came as a "protest against white domination and the moral impossibility of the promotion of blacks against a certain level". Sometime in the 1920s, there were some church bodies existing in Nigeria before the advent of the orthodox ones. They include: the Cherubim and Seraphim, Christ Apostolic in the 1930s, and others in the 1950s. These and other African churches were in search for the values that could complement their tradition and religion. Their fundamental focuses were, in the words of Oyedola, (1991: 43):

Revelation through dreams and visions, complex rituals and the separation between clean and unclean animals, the practice of polygamy, the descent of the Spirit of God upon prophets.

African fundamentalists believe in natural alliance between African Tradition and the Old Testament. Thus, such practices as Oyeshola (43), avers:

Apocalyptical and eschatological teachings, interpretation of dreams, miraculous healings and expulsion of devils and even the sharp denunciation of Pharisees, were elements of great importance to the Old and New Testaments.

These were neglected by the Protestants who feel that symbols and rituals have been eliminated. For Davidson (1980: 57), 
In the field of ritual, too many missionary churches offered nothing to replace the intricate network of ritual sacrifice and the protective amulets of traditional religion.

With the exception of the Catholic Church which promotes the use of sacraments almost to a point of superstition, Oyeshola says,

The whole complex structure of symbols, ritual, sacred space and time color and particular objects which had been intrinsically bound with the previous religious experiences of most Africans, were disgracefully disregarded.

In recent times fundamentalism has taken a business dimension as Christian religious leaders have taking Christ as a commodity to be purchased by those who have the money to buy. Ironically the ideas the protestant fundamentalists had earlier argued against are now invoked in different styles as emphasis are laid on the need to pay tit, sow seeds of faith and worshiping God for prosperity.

Let us look into the Islamic religion and their nature of fundamentalism.

\section{Islam}

Indubitably, Islam is a powerful religion that has exercised a formidable influence on the lives of the people from time immemorial. It is evident among Africans that Islam has provided a lifestyle for many; its influence and the Arabic culture are so strong in the empire states from the pre-colonial period to the present days.

The idea of Islamic fundamentalism is somewhat attached to socio-political influence they tend to play. In the words of Merteins (1980: 8)

Islam is at one and the same time a religion and a community, a faith and a civilization, a belief and a spiritual and temporal way of life; living a faith and being rooted in the Umma (Community) even though a Muslim may cease to be a believer, he still remains a member of his (Muslim) community as others have their roots in a national culture of an ethnic environment.

Islam generally exhibits an internal fundamental division and differences which are found among the orthodox Muslim (Conservatives) as well as the progressives and radicals. A careful look tells us that there are not always clear cut divisions and often not helpful to extrapolate from the Middle East situation.

The fact however remains that the Ahmadiyya and the Tijaniyya are of Islamic brotherhood. Fisher (1963: 3) avers,

The Ahmadiyya, though dynamic and present in many black African countries, is considered heretic by the orthodox Muslim.

There are Islamic associations such as JamatuNasril (Association for the Advancement of Islam) and other societies like the Izalat al-Bidawa-Iquamat as-Summa (or Izala Society for the Removal of Innovations). Izala is very significant due to its particular wide appeal to Muslim youth in the universities and towns especially here in Nigeria. There is also the Council of "Ulama", which is a body of Islamic scholars. According to Mundi (1987: 5), "Fundamentalism as the form of Islamic Revivalist Movement is also a part of the experience of African Muslim".

It is evident that the socio-political influence of Islam in the Middle East and in the African continent can be seen as manifested in its project of Islamization. This goes on to buttress what Mertein earlier avers as mentioned above.

In addition, Oyedola (1991: 37) avers, "Every Muslim is exhorted to use his influence to promote the Islamic religion wherever he finds himself'.

This explains why we find in the Nigerian universities the departments of Islamic Studies are "having a great influence on Islamization in the country" (Mertein, 12). It is therefore not surprising to see Muslim government functionaries make awards of bursaries to African students to enable them study in Arab countries such as Libya, Egypt, Saudi Arabia and Tunisia with the express purpose of advancing Islam in black Africa.

Furthermore, Islamic fundamentalism resorted to building of enormous mosques in several African countries as a way of exerting influence and marking their presence. It is on record that as at 1980, there were over 200 mosques in Dakar, Senegal. Mertein (12) avers, 
Kigali in Rwanda has an imposing central mosque and an equally imposing cultural centre. The same is true of Bajimbura, Burundi, with an immense complex of mosques, a cultural centre and a large hall.

Right in our nose is the National Mosque which is strategically positioned in the Abuja entrance from the City Gate. It could be sighted from every point in the city. It is an edifice that is self-imposing and was fundamentally completed years before the foundation of the Christian Centre was ever laid. More so are the presence of petty mosque all over the city until the administration of El Rufai which dealt a blow to wipe out all the shanties in the city including mosques and declared them illegal structures.

Fundamentally, the hope of Islam in Africa is to dominate the continent through the training of Muslim missionaries, encouraging of marriages with young women who are Christians, increasing participation in the political and economic spheres while subsiding pilgrimage to Mecca, as well as establishing national Islamic associations from one country to another. It is an ontological realism and a historical fact that in Islam, religion and state are inseparable entities. This explains why the socio-political influence of Islam is not only readily felt, but potentially undermines the government. As such the unification of Islamic religion and the state becomes a challenging issue to the cause of fundamental human rights.

Furthermore, Islamic fundamentalism in its dominant tendencies in the socio-political stratum in the world explains why she defied the infallible American security alertness by destroying the lives and properties of people in the World Trade Centre in the city of New York on September 11, 2001. In all expressions of fundamentalism, there is always an adverse state of affairs. This we shall talk about in the boomerang effect.

In Nigeria there have been several phases of fundamentalist activities beginning with the maitatsini, and now Boko haram whose activities has metamorphosed into terrorism.

\section{Ontological Boomerang Effect}

The term "Ontological Boomerang Effect” is conceptualized by Innocent Asuzu in his Philoosophy of Contemporary Reflections (2004). In his thought of being in the world, he identified the fact that being exists in "mutual complementary dependence". That being the case, he further identified a missing link where the failure to complement the existence of others brings about the non-existence of one who fails. Thus, Asuzu (2007: 39) avers:

...missing links are bound to each other in the form of entities that have mutual right to serve each other... these rights are such that a negation of them is practically the same as a negation of the being of those who are supposed to have such rights.

This implies that it is of fundamental and existential import at any level of existence to complement each other's existence. In his teaching about the anonymous traditional Igbo philosophers of the complementary way of thought, Asuzu (2007: 393) avers, "egbe bere ugo bere nke si ibe ya ebena nku kwaya" (let the kite perch, let the eagle perch, which ever denies the other the same rights, let his wings break). Thus, the negation of one's fundamental right by another is also a negation of oneself in existence. This is what he refers to as the Ontological Boomerang Effect. What this means, Asuzu further explains, is that

When an individual undertakes to negate the being of other by denying this other the right of mutual complementary service, indirectly it also boomerangs on this person who remains unserviced to his own detriment.

This boomerang effect with the characteristics of self-negation is expressed among the Igede peoplein Benue State as, "Owe la onwumnwu, o tinwuilomu"; and in Igbo language as, "Obiara-egbumgbukwaonweya". Meaning he advanced with the intention to kill me but ended up killing himself.

Furthermore, the idea of ontological boomerang is expressed among the Muslim as "Al-haki". At all times when one tends to misuse an opportunity he has gotten circumstantially, he ends up with himself. In Hausa it is said, "Kai-kai komamashekiya". In most cases, there is the self-denial which leads one to act ignorantly, giving oneself the self confidence of being smart but ending with the regretful awareness of the fact that one is not smart at all. Thus, Asuzu (396) avers,

It is a case of the tyranny of human ambivalent situations, an existential ignorance and tragedy of a special type. This is that moment where to be must translate to being-to control-failing which we risk losing our being altogether. 
Having said this, we shall now evaluate comparatively, religious fundamentalism and its boomerang effect.

\section{Evaluation}

Although it is difficult making such analysis as this, one can see from the various events across the globe, mixed-up issues being referred to as having religious undertone, especially in the Arab nations and Asian sub-regions, as well as in African countries such as Algeria, Egypt, Tunisia and Nigeria.

Islamic fundamentalism laid a foundation upon which Islam built the unification of all human races. This is expressed in the concept of unity of mankind. In his last Hajj pilgrimage to Mecca, the prophet of Islam is said to have declared before one hundred and twenty-four thousand persons,

O mankind, your God is one and you have but one father. You are all the progeny of Adam, and Adam was made of day. Lo, the noblest among you in the sight of God, is the best in conduct. No Arab has any preference over a non-Arab save his piety. (Kansul Anwar, quoted by Nadawi in The Challenge of Islam, 1978: 8).

In addition to the entrenchment of equality of the human race in the Code of Conduct of Islam, Allah says (Q-al-Hijurat 49; 13)

O mankind, we have created you from a male and female, and made you into nations and tribes, that you may know one another. Verily the most honorable of you with Allah is that (believer) who has At-taqwa (piety).

With the two quotations above it is evident that there are contrary positions held by the Muslim fundamentalists especially where they fail to adhere to injunctions, consequently there is always a boomerang effect. This is evidenced in all the activities of religious disorder around the globe especially amongst the core Muslim nations of the world. For instance, Agi (1996: 31) avers, "Religion was the chief reason for the establishment of Pakistan as an independent nation". This further implies that Pakistan was ab initio built on a wrong premise. While they talk of unity of mankind, the question remains, where is the unity of mankind where a Muslim fights a non-Muslim? Where is that unity even amongst Muslims? We have earlier seen that there are various fundamentalist groups existing among them.

Islam is said to be a way of life, and as such, its principles are subject to varied interpretations that are contrary to its basic principles. More often than not, there are occasions where boomerang effects take place as a result of fundamentalist interpretations. For instance in some states in Northern Nigeria (e.g. Sokoto, Kebbi and Katsina states), Muslims refused vaccination for polio-mellitus and other health care services provided by the government to preserve the lives of people. They fell back to accepting it only after experiencing a wide spread of the diseases. The Boko haram was a movement against western education which led so many scholars to put away their certificates because they are products of western education yet no place in the Islamic guiding principles that spells out that western education is a taboo. These are all fallacies as they contradicts the fundamentals of Islamism and imbibe erroneous and unfounded believes which are cooked up based on some persuasive arguments emanating from some scrupulous fundamentalist with the aim of dragging self sympathy to suite their purposes. And since Islam is viewed as part of the community people ignorantly fall to join and fight to save Islam not minding the consequences but they all have always lived to regret with the set back from their uncalculated actions.

Also in some states where there is a ban on alcohol, we find majority of Muslims going undercover to drink alcohol elsewhere. A typical example is that of a former governor of Niger State, Abdullahi Kure, whose son was said to have gone into the Military Cantonment in Minna in the company of his friends to drink alcohol shortly after the father had placed a ban on the sale and consumption of alcohol. He was apprehended by soldiers who demanded his father's (the governor's) presence before his release.

Contrary to the injunctions of Allah and Islamic fundamentalist way of life, as mentioned earlier, the discrimination and hatred which Arab nations have against non-Arab nations and non-Muslims in particular, is evident the world over. In the Dohan Debate in a BBC broadcast (2009) organized by the members of the Quatar Foundation with a theme which borders around the unity of the Arab, it was observed that the Arab nations are fundamentally blind to the surging and yearning of the less privileged nations even among themselves. Politically it was established in the debate by a Palestinian political analyst, Maun Robbani, that all that is being viewed as a 
result of Islamic fundamentalism is rather politically motivated. Other contributors at the debate pointed out the boomerang effect of these actions to Islamic leaders. For instance, the Trade Centre incident in America affected both Muslims and non-Muslims alike; the attack at the Public Centre in Jerusalem affected more Muslims, whereas the attack was carried out by a Muslim to hurt the Christians on pilgrimage to Jerusalem. The rigidity of the Egyptian Islamic government has affected more of the Egyptians in Diaspora. The Bokoharam is a living testimony in Nigeria. The activities of the Boko haram in recent times has shown not just an Islamic re-dress but a clear indication of politically motivated actions engineered from and by some highly placed Islamic member political leaders who have mysteriously been untouchable in the member states. In all, their actions have affected both Christians and Muslims alike.

Adam has been acclaimed by both religions the differences lie in the various interpretations by various religious leaders.

\section{Summary}

Ontologically, therefore, that Adam exists in the mind of man, creates a belief system that lacks or defies the principle directive of complementary reflection in the right direction which is rooted in the very idea of religious fundamentalism which envelopes the Existential Phenomenological Ontology of Human Predicament. This fact is reflected in the un-mutual and the resulting destabilization in some organized practices among the religious sector in the world. Adam did not exist for the disunity of mankind but the unification of mankind. This explains why the new Adam as expressed in Christianity prayed for the unification of the world "that they may be one as you and I are one".

The duo religions have preach the unity and oneness mankind and God and so there is equality of all mankind thus as Bob Marley of blessed memory puts it, until the philosophy that considers some nations superior over other nations is finally discredited and abandoned everywhere is war. That we can see that some acts of fundamentalism is born out of these ideas that some nations are superior to others and the only way to fight it is to implore some fallacies that will persuasively drive the people to sympathize with the fundamentalist.

Globalization will make no meaning where some people are considered as inferior to others. African tradition and value system remains the best to none as African culture have display reasonably the human nature of coexistence. Africans know that for one to exist he needs the existence of his fellow brother and where he fails to coexist with his brothers he fails and cannot find existence in his own being. Thus the Igede expression "unu $a$ gbachi'udo, udo ye kuroh". Meaning if a hen hops on basket, the basket will turn and cover it.

The ontological boomerang effect of religious fundamentalism calls for a deep complementary reflection, as it is obvious that nature has permitted complementarity for a peaceful co-existence. In line with Asuzu therefore, we must imbibe the spirit of complementarity as a panacea for the missing link in which being in his existence needs to co-exist with other lesser or higher beings in the society. Finally, it must be borne in mind that this life is "live and let live". For at each point we deny others their right to co-exist, we are indirectly denying ourselves the right to exist. When Cain killed Abel he defiled his own happiness.

\section{References}

Agi, S. P. I. (1996). Holy Violence (p. 31). Makurdi: Ehi Publishers.

Asuzu, I. I. (2004). The Methods and Principles of Complementary Reflection in and Beyond African Philosophy (pp. 110-118). Calabar: UNICAL Press.

Asuzu, I. I. (2007). Ibuanyidanda (pp. 39, 393, 396). Livingston: Transaction Publishers.

BBC (2009). Doha Debate, September $8^{\text {th }}, 2009$.

Davidson, B. (1984). The Story of Africa (p. 57). London: Mitchell Bentley Publisher.

Fisher \& Amadiyya (1963). A Study in Contemporary Islam on West African Coast (p. 3). Oxford: Oxford University Press.

Mertein, U. (1980). The New Vitality of Islam in Black Africa and Its Pastoral Implications (pp. 8, 12). Kanistein: Kim/Oph.

Mundi, V. (1987). N. 109, Brussels (p. 5).

Oyedola, D. A. (1991). Religious Obstacles to Development. Orita: Ibadan Journal of Religious Studies, xxiii, $37,43$.

Webster (2004). The New Webster’s Comprehensive Dictionary of the English Language Encyclopedic Edition (p. 512). USA: Trend int'l Press. 